\title{
Editorial: The New (African) Regionalism in International Investment Law
}

It is by now a truism that international investment law is a fast-evolving field. This holds true not only in the jurisprudence produced by arbitral tribunals, but also in treaty making. Indeed, we have come a long way from the lean, Europeanstyle model bilateral investment treaty (BIT) that has dominated international investment agreement (IIA) practice until the mid-20oos. Since then, the recalibration of investor rights, the integration of trade and investment matters in the same agreement and debates about redesigning investment dispute settlement are the dominant trends in investment treaty making.

Rising regionalism, including the involvement of regional organizations as parties to IIAs, as well as the conclusion of regional investment agreements among members, is another marked feature. Finally, changes to the geography of international investment law are notable. Developments in the field are, for a variety of reasons, not anymore dominated by capital-exporting countries from North America and Western Europe, but occur in places that have long been considered as 'periphery'. Here again, regions, rather than individual countries, seem to have the most far-reaching impact.

In order to map and critically evaluate these developments, the Journal of World Investment and Trade has put a particular focus on regionalism in the practice, debates and intellectual engagement with investment law and policy in a number of Special Issues. After dealing with the emerging investment law and policy of the European Union (EU) under the Lisbon treaty (15:3-4 JWIT (2014) 375-704), the rising impact of Asian actors in investment governance (16:5-6 JWIT (2015) 765-1124), the challenges to the system in Latin America (17:4 JWIT (2016) 511-699), and the legal problems of intra-EU IIAs (17:6 JWIT (2016) 871-1051), the present Special puts developments in Africa on center stage.

It is hardly an exaggeration to say that the developments there are at the cutting edge of debates in international investment law and policy. Not only are all major trends in IIA-making mirrored in Africa; in several respects African actors may even be frontrunners in the field and help make a unique contribution to regionalism in international investment governance. This 
holds true, for example, in respect of how obligations of foreign investors an issue that is hotly debated at the United Nations level, with a multilateral convention on business and human rights looming - are integrated into IIAs. In this respect, various projects of investment law reform in Africa go much beyond the suggestions made elsewhere, including in Europe and Latin America. Similarly, the focus on investment facilitation for sustainable development in several projects of regional economic integration in Africa is much more pronounced than in other regions.

The idea of a new regionalism in investment governance in Africa also shows in respect of how regional organizations, such as the Common Market for Eastern and Southern Africa (COMESA), the East African Community (EAC), the Southern African Development Community (SADC), or the African Union (AU), position themselves in the dynamic investment policy processes in Africa. Rather than set out to disintegrate and enhance the spaghetti bowl of bilateral arrangements, they aim at disentangling it. African regional organizations not only coordinate their members' investment policies, but also engage in inter-organization cooperation in order to achieve much broader projects of regional economic integration. These culminate in the creation of an Africawide free trade area with an integrated foreign investment policy of which the Pan-African Investment Code (PAIC) is the most tangible manifestation. While such a grand project is still to materialize, it seems that African states and organizations use regionalism as building blocks towards more economic integration and (sustainable) development. Unlike in some regions elsewhere, African regionalism is less an expression of fragmentation or the result of conflicting internal or external interests pulling in different directions, but a constructive step in defragmentation.

Finally, the developments in international investment law and policy in Africa are driven - to a large part - from within Africa. This is not only the case at the level of policy-makers, but also at the level of experts. The work on the PAIC, for example, has relied predominantly on African rather than foreign experts. Similarly, the Principles on International Investment for Sustainable Development in Africa developed by the African Society of International Law are an expression of genuinely African engagement with investment law. Far from suggesting that they are sealed-off from debates elsewhere, an African approach is helpful in bringing about projects of investment governance that are viewed as genuinely African in reflecting African values and understandings.

While some of the projects discussed in this Special Issue are still visions, and are yet to stand the challenge of being put into practice, the specific features African regionalism in investment governance already has developed can also serve as a useful example for how regional integration in investment 
law and policy can lead to consolidation and ensure legitimacy in investment governance elsewhere. If other regions were to follow the African example, the development of multilateral rules and institutions that are based on genuine consensus could greatly advance.

Stephan W. Schill*

* Support in editing this Special Issue as part of the European Research Council Starting Grant on 'Transnational Private-Public Arbitration as Global Regulatory Governance: Charting and Codifying the Lex Mercatoria Publica' (LexMercPub - Grant Agreement No 313355) carried out at the Amsterdam Center for International Law (ACIL) of the University of Amsterdam is gratefully acknowledged. 